\title{
Chair dimension compatibility with elementary school students anthropometric data in North Jakarta
}

\author{
Hiromi, ${ }^{1}$ Yunisa Astiarani, ${ }^{2}$ Robi Irawan, ${ }^{3}$ Mariani Santosa ${ }^{4}$
}

\begin{abstract}
\section{BACKGROUND}

In Indonesia, primary school begins at 6 years old and continues until 12, where most of their growth is experienced at that age. Nonergonomic school furniture can harm the musculoskeletal system. This study evaluates the suitability of chair dimensions to elementary school student's anthropometry in North Jakarta.
\end{abstract}

\section{METHODS}

A cross-sectional study of 98 students in North Jakarta. Chair dimension data and student anthropometry were measured using a tape measure, which was then analyzed using the Chi-Square Goodness of Fit Test to evaluate their suitability.

\section{RESULTS}

The ages of the students ranged from 5 to 11 years. Anthropometric measurements of students show that the mean Sitting Shoulder Height is $41.81 \pm 4.36 \mathrm{~cm}$, Popliteal Height $36.83 \pm 3.77 \mathrm{~cm}$, Hip Breadth $25.88 \pm 3.47 \mathrm{~cm}$, and Buttock-Popliteal Length $36.56 \pm 4.33 \mathrm{~cm}$. While the average size assessed from the seat dimensions is Seat Height $41.71 \pm 0.22$ $\mathrm{cm}$, Seat Width $37.2 \pm 1.26 \mathrm{~cm}$, Seat Depth $37.2 \pm 1.42 \mathrm{~cm}$, and Backrest Height Above Seat $35.54 \pm 3.19 \mathrm{~cm}$. The results of Goodness of Fit with Kendall's Tau-b critical value for the suitability of chair dimensions to student anthropometry were 0.37 , and vice versa 0.672 , which stated a discrepancy.

\section{CONCLUSION}

There is a mismatch between chair dimension and anthropometry of elementary school students in North Jakarta. Adjustment of chair dimensions needs to be done using a student's average size approach to prevent musculoskeletal disorders.

Keywords: anthropometry, chair dimensions, ergonomics, elementary school

\author{
${ }^{1}$ Bachelor of Medicine Study \\ Programme, School of Medicine and \\ Health Sciences, Atma Jaya Catholic \\ University of Indonesia, Jakarta, \\ Indonesia \\ ${ }^{2}$ Department of Public Health and \\ Nutrition, School of Medicine and \\ Health Sciences, Atma Jaya Catholic \\ University of Indonesia, Jakarta, \\ Indonesia \\ ${ }^{3}$ Department of Anatomy, School of \\ Medicine and Health Sciences, Atma \\ Jaya Catholic University of Indonesia, \\ Jakarta, Indonesia \\ ${ }^{4}$ Department of Physiology, School of \\ Medicine and Health Sciences, Atma \\ Jaya Catholic University of Indonesia, \\ Jakarta, Indonesia
}

\section{Korespondensi:}

Hiromi

School of Medicine and Health

Sciences, Atma Jaya Catholic

University of Indonesia, Jakarta, Indonesia

Jalan Pademangan 3 Gang 9 No. 6, North Jakarta, 14410

Email:

hiromi.201706000008@student. atmajaya.ac.id

\footnotetext{
J Biomedika Kesehat 2021;4(1):12-18 DOI: $10.18051 /$ JBiomedKes.2021. v4.12-18

pISSN: 2621-539X / eISSN: 2621-5470

Artikel akses terbuka (open access) ini didistribusikan di bawah lisensi Creative Commons Attribution 4.0 International (CC-BY 4.0)
} 


\section{ABSTRAK}

\section{Kesesuaian dimensi kursi terhadap data antropometri anak sekolah dasar di Jakarta Utara}

\section{LATAR BELAKANG}

Di Indonesia, sekolah dasar (SD) dimulai saat anak-anak berusia 6 tahun hingga 12 tahun di mana sebagian besar pertumbuhan mereka dialami pada usia tersebut. Perabot belajar yang tidak ergonomis dapat menimbulkan efek buruk pada tulang belakang siswa SD. Penelitian ini bertujuan untuk mengevaluasi kesesuaian dimensi kursi terhadap antropometri siswa sekolah dasar di Jakarta Utara.

\section{METODE}

Penelitian potong lintang pada 98 siswa di Jakarta Utara. Data dimensi kursi dan antropometri siswa diukur dengan menggunakan pita meteran yang kemudian dianalisis dengan Uji Chi-square Goodness of Fit untuk mengevaluasi kesesuaiannya.

\section{HASIL}

Usia siswa memiliki rentang usia 5 hingga 11 tahun. Ukuran antropometri siswa menunjukkan bahwa rerata Sitting Shoulder Height adalah $41.81 \pm 4.36 \mathrm{~cm}$, Popliteal Height $36.83 \pm 3.77 \mathrm{~cm}$, Hip Breadth $25.88 \pm 3.47 \mathrm{~cm}$, dan Buttock-Popliteal Length $36.56 \pm 4.33 \mathrm{~cm}$. Sedangkan rerata ukuran yang dinilai dari dimensi kursi adalah Seat Height $41.71 \pm 0.22 \mathrm{~cm}$, Seat Width $37.2 \pm 1.26 \mathrm{~cm}$, Seat Depth $37.2 \pm 1.42 \mathrm{~cm}$, dan Backrest Height Above Seat $35,54 \pm 3.19 \mathrm{~cm}$. Hasil Goodness of Fit dengan nilai kritis Kendall's Tau-b untuk kesesuaian dimensi kursi terhadap antropometri siswa adalah 0.37 , dan sebaliknya 0.672 yang menyatakan ketidaksesuaian.

\section{KESIMPULAN}

Terdapat ketidaksesuaian antara dimensi kursi dan antropometri siswa sekolah dasar di Jakarta Utara. Penyesuaian dimensi kursi perlu dilakukan dengan pendekatan rerata ukuran antropometri untuk mencegah gangguan muskuloskeletal.

Kata kunci: antropometri, dimensi kursi, ergonomis, sekolah dasar

\section{INTRODUCTION}

Low back pain is a symptom due to disruption or disturbance in the arrangement and movement of the back's components, such as spine, muscles, intervertebral discs, and nerves..$^{(1)}$ Based on a systematic analysis conducted by Mboi et al. ${ }^{(2)}$, low back pain ranks in the top four due to its high impact on disability. Low back pain is more common in adult, however, the rising complaint in school-age children cannot be neglected.

One of the causes of low back pain in school-age children is the wrong sitting posture for a long time and excessive backpack load. $(1,3)$ Several previous studies found quite high prevalence of musculoskeletal disorders in students from different age groups. A study in Brazil found that $4.1 \%$ of students had scoliosis. In Portuguese children, the prevalence of kyphosis, lordosis, and scoliosis are $16.6 \%, 27.9 \%$, and $33.2 \%$, respectively. In addition, lordosis was found to be more frequent at age 8 to 12 years, while scoliosis was more frequent in boys than girls. ${ }^{(4)}$ In Indonesia, people have to attend school since they are six years old, as stated in the Law of the Republic Indonesia Number 20 of 2003 Chapter VIII Article 34 concerning Compulsory Education. ${ }^{(5)}$

Children in school need well-designed school furniture because poorly designed furniture will limit posture when doing classroom activities, such as writing and reading, which will affect children's performance at school. ${ }^{(6)}$ Besides, school furniture design also affects the concentration of the students. ${ }^{(7)}$ Products or furniture that are made or designed adequately based on its users can also be called ergonomics. ${ }^{(8)}$ This is because ergonomics' basic philosophy is to create furniture or products that can support comfort, physical health, safety, well-being, and motivation to study. (6) Anthropometry is the standard method that uses standard instruments and techniques to measure various parts of the body. ${ }^{(9)}$ According to Katrin et al. ${ }^{(10)}$, ergonomy is the utilization of principles, methods, and scientific data from various fields to develop a system in which people have a big role in it. However, based on a study by Hoque et al. ${ }^{(11)}$, the dimension of chairs used in primary schools in Bangladesh were not suitable according to their students' anthropometry as well as the results of study in Egypt ${ }^{(12)}$. In Indonesia, the dimension of chairs at Early Childhood Education and International Schools in Siwalankerto, Surabaya did not match the anthropometry of students, as stated by Novita et al. ${ }^{(13)}$ and Jennie et al. ${ }^{(14)}$

The usage of furniture that is not suitable to the user's anthropometry can cause anatomical 


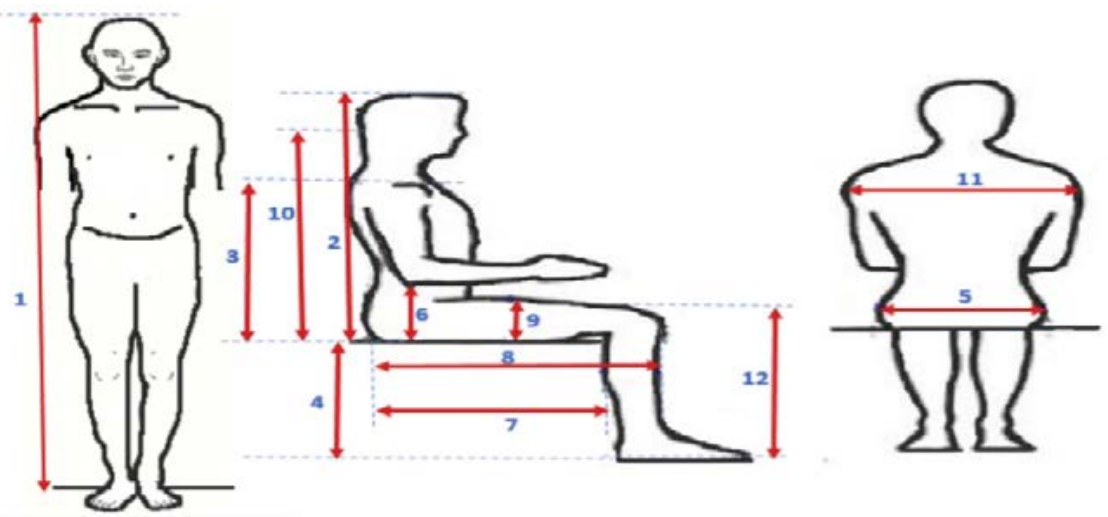

Figure 1: Anthropometric data for classroom furniture design ${ }^{(6)}$

(1) Stature; (2) Sitting Height (3) Sitting Shoulder Height; (4) Popliteal Height; (5) Hip Breadth; (6) Elbow Sitting Height; (7) Buttock-Popliteal Length; (8) Buttock-Knee Length; (9) Thigh Clearance; (10) Sitting Eye Height; (11) Shoulder Breadth; (12) Sitting Knee Height

and functional changes and cause problems in the studying process. ${ }^{(15)}$ This can lead to abnormalities in musculoskeletal development and cause pain in the upper back, neck, and lower back ${ }^{(11)}$ due to the poor sitting posture of the students who are adjusted to chairs that do not fit with the dimensions of the students' body. ${ }^{(3)}$ Besides, the growth and development difference among school-age children also needs to be considered in designing school furniture such as chairs so that anatomical abnormalities resulting from using inappropriate chairs can be prevented. ${ }^{(15)}$

According to a previous study, students' anthropometric measurements in schools are essential for Asian populations in ergonomic school furniture design. ${ }^{(6)}$ However, there are not many studies that analyze the compatibility of chairs to anthropometric data in Jakarta. In fact, the diversity of races and ethnicites in Jakarta's population, also cause variations of body dimensions or anthropometric dimensions. ${ }^{(8)}$ The differentiation of socioeconomic degree such as education, nutrition, child care, also medical and social services also effect on the variation of anthropometric dimensions in the population. ${ }^{(16)}$ Base on this fact, researchers were interested in analyzing chair dimensions against anthropometry among elementary school students to find out whether the design of school furniture, especially chairs, used in the elementary school has been adjusted to the average of anthropometric data of Indonesian students. In the future, this study can be used as an initial study and reference for further studies, both for policy and regulation-making in designing ergonomics chairs for elementary schools as a step of prevention and risk reduction of musculoskeletal disorders.

\section{METHODS}

A cross-sectional study was conducted on 98 elementary students from an Elementary School in North Jakarta. The study participants were selected by simple random sampling after the school and parents waived the consent. The study's inclusion criteria were elementary school students attending the chosen school from grades 1 to 6 and cooperating with the study. Students with spine abnormalities, such as kyphosis, lordosis, scoliosis, and students with disabilities or physical disabilities were excluded. The measurement tape was employed to measure students' anthropometry and chair dimensions. The anthropometric measurements were performed by trained staff under a nutrition specialist's supervision. Students were measured in the upright body position while the popliteal or behind the knees against the chair end. The measurements included sitting shoulder height, popliteal height, hip breadth, and buttock popliteal length (Figure 1). The chair dimensions were obtained from 6 representative chairs from each class due to size similarity. The chair dimensions included seat height, seat width, seat depth, backrest height above the seat. Birthdate information was obtained using a questionnaire filled by the student's legal guardian. The data were analyzed using the Chi-square goodness of fit test performed in Software for Statistics and Data Science (STATA) Version 15 for Windows. 
Table 1. Students' anthropometrics and chair ergonomic measurement data

\begin{tabular}{llcccc}
\hline & & Min & Max & Mean & SD \\
\hline \multirow{4}{*}{ Anthropometry } & Sitting Shoulder Height $(\mathrm{cm})$ & 34 & 55.5 & 41.81 & 4.36 \\
& Popliteal Height $(\mathrm{cm})$ & 29.4 & 46 & 36.83 & 3.77 \\
& Hip Breadth $(\mathrm{cm})$ & 18.8 & 36 & 25.88 & 3.47 \\
& Buttock-Popliteal Length $(\mathrm{cm})$ & 27 & 48 & 36.56 & 4.33 \\
& Seat Height $(\mathrm{cm})$ & 41.5 & 42 & 41.71 & 0.22 \\
Chair Ergonomic & Seat Width $(\mathrm{cm})$ & 36 & 38.5 & 37.2 & 1.26 \\
Measurement & Seat Depth $(\mathrm{cm})$ & 35.5 & 39 & 37.2 & 1.42 \\
& Backrest Height Above Seat $(\mathrm{cm})$ & 32.5 & 39 & 35.54 & 3.19 \\
\hline
\end{tabular}

\section{RESULTS}

Demographic data from 98 students from 1 st to 6 th grade, including gender and age, were obtained by the questionnaire, and body weight and height were measured by trained staff using SECA digital scales and a stadiometer. The boy's mean age ranging from 5.8 to 10.9 years old, while the girl's mean age range is 5.7 to 10.8 years old. The mean body weight ranges from 23.6 to $44.5 \mathrm{~kg}$ for boys and 23.4 to $43.8 \mathrm{~kg}$ for girls. Meanwhile, the mean range of body height is $116.3-141.6 \mathrm{~cm}$ and $112.8-144.7 \mathrm{~cm}$ for boys and girls, respectively. Anthropometric data of 98 students and chair dimensions were stated in Table 1.

Adjustments were made to the chair dimension and anthropometric data obtained, as recommended by Castellucci et al. ${ }^{(15)}$ study, on calculating ergonomic measures range that need to be adjusted to student anthropometry (Table 2 ). The percentage of non-conformity shows that the student's anthropometric size is greater or smaller than the chair ergonomic reference, based on the student's grade, and shown in Table 3 . The slightest mismatch is found in the size of seat depth in 2nd-grade $(28,57 \%)$. On the other hand, a hundred percent of mismatch was found in the seat width and backrest height, meanwhile the seat height, $100 \%$ mismatch found in 1 st and 2nd-grade.

Student anthropometry and ergonometric chair data were then analyzed using the Chi-square Goodness of fit method using the STATA software. The results are presented in Table 4. Based on the analysis results, it can be concluded that there is a significant ergonomic mismatch between chairs' ergonomic against students' anthropometric data and vice versa.

\section{DISCUSSION}

Students' characteristic data complied to Rosyidi et al. ${ }^{(17)}$ study which showed an increase in age, weight, and height along with increasing age, with the most massive increase in body weight and height were from $3^{\text {rd }}$ grade to $4^{\text {th }}$ grade. The anthropometric measurement from this study showed that the weight and height of the students were smaller except for the girls in $3^{\text {rd }}$ and $5^{\text {th }}$ grade compared to Rosyidi. et al study. ${ }^{(17)}$ Meanwhile, compared to one study in America by Oyewole et al. ${ }^{(18)}$, the weight and height of this study's samples were bigger.

Based on the growth chart published by the Centers for Disease Control and Prevention (CDC) (19), there is a regular increase in body weight and height at primary school age, which is in the range of 5-11 years. However, there is a rapid increase in body weight in both boys and girls in grade 4

Table 2. Ergonomic size range of seats by class

\begin{tabular}{ccccc}
\hline \multirow{2}{*}{ Grade } & \multicolumn{4}{c}{ Ergonomic Size Range of Seats } \\
\cline { 2 - 5 } & Seat Height $(\mathbf{c m})$ & Seat Width $(\mathbf{c m})$ & Seat Depth $(\mathbf{c m})$ & $\begin{array}{c}\text { Backrest Height } \\
\text { Above Seat }(\mathbf{c m})\end{array}$ \\
\hline 1 & $36.96-39.9$ & $42.35-50.05$ & $31.2-37.44$ & $23.1-30.8$ \\
2 & $36.52-39.425$ & $39.6-46.8$ & $28.4-34.08$ & $19.5-26$ \\
3 & $36.696-39.615$ & $39.6-46.8$ & $28.8-34.56$ & $19.5-26$ \\
4 & $36,96-39.9$ & $39.6-46.8$ & $28.8-34.56$ & $19.5-26$ \\
5 & $36.52-39.425$ & $42.35-50.05$ & $30.8-36.96$ & $23.4-31.2$ \\
6 & $36.52-39.425$ & $42.35-50.05$ & $30.8-36.96$ & $23.4-31.2$ \\
\hline
\end{tabular}


Table 3. Percentage of mismatch in chair ergonomic data against student anthropometric data

\begin{tabular}{lllllll}
\hline \multicolumn{1}{c}{ Variable } & \multicolumn{6}{c}{ Grade } \\
\cline { 2 - 7 } & \multicolumn{1}{c}{$\mathbf{1}$} & $\mathbf{2}$ & $\mathbf{3}$ & \multicolumn{1}{c}{$\mathbf{4}$} & \multicolumn{1}{c}{$\mathbf{5}$} & $\mathbf{6}$ \\
\hline Seat Height $(\mathrm{cm})$ & $100 \%$ & $100 \%$ & $75 \%$ & $63.16 \%$ & $86.67 \%$ & $94.12 \%$ \\
Seat Width $(\mathrm{cm})$ & $100 \%$ & $100 \%$ & $100 \%$ & $100 \%$ & $100 \%$ & $100 \%$ \\
Seat Depth $(\mathrm{cm})$ & $40 \%$ & $28.57 \%$ & $50 \%$ & $89.47 \%$ & $60 \%$ & $94.12 \%$ \\
Backrest Height $(\mathrm{cm})$ & $100 \%$ & $100 \%$ & $100 \%$ & $100 \%$ & $100 \%$ & $100 \%$ \\
\hline
\end{tabular}

students, followed by a decrease in the mean value in $5^{\text {th }}$ grade. In the male sample, mean body weight ranged from the $50^{\text {th }}$ percentile to more than the $95^{\text {th }}$ percentile, and mean height ranged from the $25^{\text {th }}$ percentile to the $75^{\text {th }}$ percentile. In the female sample, mean body weight ranged from the $25^{\text {th }}$ percentile to the $90^{\text {th }}$ percentile, and mean height ranged from the $10^{\text {th }}$ percentile to the $75^{\text {th }}$ percentile. The largest percentile of body weight for the age was found in the $4^{\text {th }}$ grade, which was more than the $95^{\text {th }}$ percentile for boys and girls' $90^{\text {th }}$ percentile. Student anthropometric dimensions were measured using a tape measure on 98 students, including popliteal height, hip breadth, buttock-popliteal length, and sitting shoulder height, which was selected based on the dimension data on the chairs at the chosen elementary school. Chair dimension data, including seat height, seat width, seat depth, and backrest height above the seat, were measured using a tape measure on six elementary school chairs. The six chairs measured were representatives of each class because it was found that the chairs in all classes of one grade has similar size and design. From the six different chairs from each grade, it was found that the chairs used in the school had two designs, namely the same design for $1^{\text {st }}, 5^{\text {th }}$, and $6^{\text {th }}$ grade, and the other design were used by $2^{\text {nd }}, 3^{\text {rd }}$, and $4^{\text {th }}$ grade. The largest difference between chairs with the same design is $0.5 \mathrm{~cm}$.

This is similar to the results of a study conducted in Central Java. ${ }^{(17)}$ In fact, similar seat sizes in highly different grade groups such as $1^{\text {st }}$ grade and $6^{\text {th }}$ grade are not following ergonomic principles which is a product is designed based on its user. ${ }^{(8)}$ If these ergonomic principles were violated, the user will be sitting in a posture that is not good to optimize his/her job. In this case, the student's job is to study at school. Poor sitting posture due to inappropriate ergonomics of chairs can also lead to musculoskeletal developmental disorders, such as pain in the upper back, neck, and lower back. ${ }^{(11)}$

From the anthropometric data of $1^{\text {st }}$ to $6^{\text {th }}$ grade elementary school students and dimension data from six chairs, the researcher conducted a compatibility analysis with the Goodness of Fit principle of Chi-square and STATA. The result is that there is incompatibility of ergonomic data to anthropometric data and vice versa. This result is similar to several previous studies. A study in several primary schools in Central Java, Indonesia, found a mismatch between the student with the tables and chairs, with a high mismatch found in the size of the seat height and seat depth. (17) Additionally, another study of three secondary schools in Akure, Nigeria, also had high mismatch rates between student anthropometric measures and school furniture size. ${ }^{(20)}$ From this study, it was found that there was a significant mismatch between the anthropometric measurements of students and their class furniture.

The study of furniture in early childhood education centers and international schools was also considered not suitable for the anthropometry of their students. ${ }^{(13)}$ Another study found that the furniture at Siwalankerto early childhood education center was not ideal for their students. (14) This raises the need for a survey of furniture dimension based on the anthropometry. Also,

Table 4. Ergonomic suitability of anthropometric and anthropometry of ergonomics

\begin{tabular}{lrrrrrr}
\hline \multirow{2}{*}{ Critical Value } & \multicolumn{3}{c}{ Ergonomic - Anthropometry } & \multicolumn{2}{c}{ Anthropometry - Ergonomic } \\
\cline { 2 - 7 } & \multicolumn{1}{c}{$\mathbf{X}^{\mathbf{2}}$} & $\boldsymbol{P}$ value & Information & $\mathbf{X}^{\mathbf{2}}$ & P value & Information \\
\hline Kendall's Tau-b & 0.37 & 0.002 & Low correlation & 0.672 & 0.000 & Low \\
Kendall's Tau-c & 0.371 & 0.002 & & 0.636 & 0.000 & \\
Gamma & 0.583 & 0.002 & & 1 & 0.000 & \\
\hline
\end{tabular}


the change in body size and age raises the need to apply anthropometric measurement results in making furniture sizes so that they are ergonomic. The study also found that students' anthropometric data will increase along with increasing age, so that furniture of the same size will not fit with children of all age groups. ${ }^{(12)}$ A study in Bangladesh found a high mismatch between school students' body dimensions and the dimensions of classroom furniture. ${ }^{(11)}$ Also, the furniture dimensions are in an unfavorable range, which can cause discomfort, pain, and musculoskeletal problems.

The mismatch between furniture dimension and users' anthropometric could happen because the furniture designer does not have anthropometric data or only relies on other countries' anthropometric data. Furniture dimension's incompatibility with anthropometry can have several health impacts because it triggers anatomical and functional changes and cause problems in the learning process. For example, a seat that is too high can put pressure on the underside of the thigh, which will lead to discomfort and poor blood circulation to the legs. On the other hand, if the seat is too low, most of the bodyweight will be centered on the ischial tuberosity. Another example is a chair that is too deep or too big on the seat depth tends to put a lot of pressure on the popliteal area that cut off the blood supply to the thigh. On the other hand, on a shallow chair, the lower thigh tends to hang and result in a poor sitting posture. Seat height and seat depth that do not match with the user's anthropometry cause users tend to adjust their sitting posture to compensate for their chairs' mismatch to a kyphotic sitting posture, which can cause spinal pain. ${ }^{(15,20)}$ A previous study found that about $58 \%$ of the students had been absent at least once a month due to aches and pains that resulted from their sitting postures in class. ${ }^{(18)}$

The limitation of this study is that health problems, such as anatomical abnormalities, as a result of the incompatibility of chair ergonomics and students' anthropometry were not obtained because it was difficult to be understood by the samples who were elementary school students. Besides, health problems are not only caused by inappropriate usage of chairs, so they cannot be assessed by the cross-sectional study that is only seen at one time. Therefore, if you want to carry out a physical examination that arises as a result of a chair dimension's mismatch, it is necessary to carry out periodic health checks to observe the relationship of the impact from an incompatibility between chair dimensions with students' anthropometry. The school only allowed limited time for measurement and also did not allow for a thorough examination. Another limitation of this study is that the subjects are not representative of all primary school students in the North Jakarta area. There may be variations in school facilities at schools with different socioeconomic degree.

\section{CONCLUSION}

Based on this study results that have been described, it can be concluded that there is a mismatch between the dimension of chairs in elementary schools and the anthropometry of students at an elementary school in North Jakarta. To find out more about the consequences of ergonomic incompatibility with anthropometry, it is advisable to conduct systematic research to examine posture complaints as one of the consequences. It is also suggested to achieve a similar study in several schools with different socioeconomic degree from this study to obtain more representative data for the student population in North Jakarta. It is also recommended for medical personnel to educate the public about the importance of adjusting the chair's ergonomic with the user's anthropometry.

\section{ACKNOWLEDGEMENT}

The author of this manuscript would like to thank the Department of Public Health and Nutrition, School of Medicine and Health Sciences, Atma Jaya Catholic University of Indonesia for letting the author collect data. The author also would like to thank everyone who participated in collecting the data and for emotional support.

\section{CONFLICT OF INTEREST}

Competing interests: No relevant disclosures

\section{CONTRIBUTORS}

H: Conception and design of study, Acquisition of data, Analysis and/or interpretation of data, Drafting the manuscript, Revising the manuscript critically, Approval of the version of the manuscript to be published; YA: Conception 
and design of study, Acquisition of data, Analysis and/or interpretation of data, Revising the manuscript critically, Approval of the version of the manuscript to be published; RI: Conception and design of study, Revising the manuscript critically, Approval of the version of the manuscript to be published; MS: Revising the manuscript critically, Approval of the version of the manuscript to be published

\section{REFERENCES}

1. National Institute of Neurological Disorders and Stroke. Low Back Pain Fact Sheet [Internet]. Bethesda, MD: National Institute of Neurological Disorders and Stroke; 2020 [updated $2020 \mathrm{Apr}$ 27; cited 2020 Nov 16]. Available from: https:// www.ninds.nih.gov/Disorders/Patient-CaregiverEducation/Fact-Sheets/Low-Back-Pain-FactSheet

2. Mboi N, Murty Surbakti I, Trihandini I, et al. On the road to universal health care in Indonesia, 1990-2016: a systematic analysis for the Global Burden of Disease Study 2016. The Lancet. 2018;392(10147):581-591. doi: 10.1016/S01406736(18)30595-6

3. Dianat I, Karimi MA, Asl Hashemi A, et al. Classroom furniture and anthropometric characteristics of Iranian high school students: Proposed dimensions based on anthropometric data. Appl Ergon. 2013;44(1):101-108. doi: 10.1016/j.apergo.2012.05.004

4. Zakeri Y, Baraz S, Gheibizadeh M, et al. Prevalence of Musculoskeletal Disorders in Primary School Students in Abadan-Iran in 2014. Int $\mathbf{J}$ Pediatr. 2016;4(25). doi: 10.22038/IJP.2016.6265

5. Undang-undangNomor20tahun2003 tentang Sistem Pendidikan Nasional [Internet]. Jakarta: Sekretaris Negara Republik Indonesia; 2003 [cited 2020 Nov 16]. Available from: https://jdih.kemenkeu.go.id/ fulltext/2003/20TAHUN2003UU.htm

6. Taifa IW, Desai DA. Anthropometric measurements for ergonomic design of students' furniture in India. Eng Sci Technol Int J. 2017;20(1):232-9. doi: 10.1016/j.jestch.2016.08.004

7. Abdullah RN, Ahmad AN. Evaluation of ergonomic design of desk and chair for primary schools in Erbil City. Int Trans J Eng Manag Sci Tech. 2020;11(6): 11A06T: 1-10. doi: 10.14456/ itjemast.2020.120

8. Pheasant S, Haslegrave CM. Bodyspace: Anthropometry, ergonomics and the design of work. $3^{\text {rd }}$ ed. Boca Raton, FL: CRC Press; 2005.

9. Lucas $T$, Henneberg $M$. Use of units of measurement error in anthropometric comparisons. Anthropol Anz. 2017;74(3):183-192. doi: 10.1127/ anthranz/2017/0628

10. Elbert KK, Kroemer HB, Hoffman ADK. Ergonomics: how to design for ease and efficiency. $3^{\text {rd }}$ ed. London: Academic Press; 2018.

11. Hoque ASM, Parvez MS, Akram W, et al. Ergonomic design of classroom furniture for High School students of Bangladesh [Internet]. SSRG International Journal of Industrial Engineering. 2016;3(2):1-7. Available from: http:// WWw.internationaljournalssrg.org/IJIE/paper- details? Id $=24$

12. Rahman SAA, Shaheen AAM. Anthropometric Consideration for Designing Classroom Furniture in Arabic Primary and Preparatory Boys Schools [Internet]. Bull. Fac. Ph. Th. Cairo Univ 2008;13(1):343-357. Available from: http://www. lib.pt.cu.edu.eg/34-Samia\%20Jan\%202008.pdf

13. Siaul N, Wibowo M, Rizqi T. Analisis Ergonomi Terhadap Desain Mebel Pada Sekolah Anak Usia Dini Dengan Antropometri Anak Usia 2-3 Tahun [Internet]. Jurnal Intra. 2018;6(2):83-93. Available from: http://publication.petra.ac.id/index.php/ desain-interior/article/view/7163

14. Hasimjaya J, Wibowo $M$, Wondo $D$, et al. Kajian Antropometri \& Ergonomi Desain Mebel Pendidikan Anak Usia Dini 3-4 Tahun di Siwalankerto [Internet]. Jurnal Intra. 2017;5(2):449-459. Available from: http:// publication.petra.ac.id/index.php/desain-interior/ article/view/5858

15. Castellucci HI, Arezes PM, Molenbroek JF. Analysis of the most relevant anthropometric dimensions for school furniture selection based on a study with students from one Chilean region. Appl Ergon. 2015;46 Pt A:201-11. doi: 10.1016/j. apergo.2014.08.005

16. Chuan TK, Hartono M, Kumar N. Anthropometry of the Singaporean and Indonesian populations. Int $J$ Ind Ergon. 2010;40(6):757-66. doi: 10.1016/j. ergon.2010.05.001

17. Rosyidi CN, Susmartini S, Purwaningrum L, et al. Mismatch Analysis of Elementary School Furniture in Several Regions of Central Java, Indonesia, and Redesign Recommendations. SAGE Open. 2016;1 9. doi: 10.1177/2158244016664386

18. Oyewole SA, Haight JM, Freivalds A. The ergonomic design of classroom furniture/computer work station for first graders in the elementary school. Int J Ind Ergon. 2010;40(4):437-47. doi: 10.1016/j.ergon.2010.02.002

19. CDC. Growth Charts - Clinical Growth Charts [Internet]. US: CDC; 2019 [cited 2020 Nov 16]. Available from: https://www.cdc.gov/ growthcharts/clinical_charts.htm

20. Obinna FP, Sunday AA, Babatunde O. Ergonomic assessment and health implications of classroom furniture designs in secondary schools: a case study. Theor Issues Ergon Sci. 2021:22(1);1-14. doi: $10.1080 / 1463922$ X.2020.1753259 